\title{
Effect of pituitary extract, ovaprim and combination of human chorionic gonadotropin and metoclopramide on reproductive performance of Caspian shemaya, Alburnus chalcoides (Guldenstadt, 1772)
}

\author{
MAJID NOSRATI, HOSSEIN KHARA*, HABIB VAHABZADEH AND \\ SAYEED FAKHREDIN MIRHASHEMI NASAB \\ Inland Water Aquaculture Research Center, Iranian Fisheries Science Research Institute, Agriculture Research \\ Education and Extension Organising (REEO), Bandar Anzali, Iran \\ *Department of Fishery, Lahijan Branch, Islamic Azad University, Lahijan, Iran \\ e-mail:h.khara1974@yahoo.com
}

\begin{abstract}
The present study was conducted to examine the effects of three different hormonal treatment types i.e., pituitary extract $(\mathrm{Pt})$, ovaprim (Ov) and human chorionic gonadotropin (HCG) + Metoclopramide (Met) on reproductive performance of Caspian shemaya, Alburnus chalcoides (Guldenstadt, 1772). To this end, three experimental treatments and one control group were considered. The experimental groups were administrated with different doses of Pt, Ov, HCG+Met as follows: $\mathrm{Pt}-2 \mathrm{mg}$

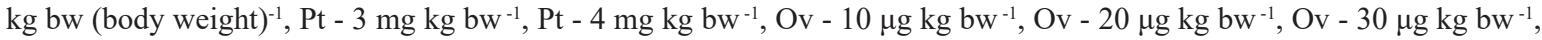
HCG+Met - $1000 \mathrm{IU} \mathrm{kg} \mathrm{bw}^{-1}$, HCG+Met - $2000 \mathrm{IU} \mathrm{kg} \mathrm{bw}^{-1}$, HCG+Met - $3000 \mathrm{IU} \mathrm{kg} \mathrm{bw}^{-1}$ and also a control group without any hormonal treatment. The highest values of oocyte weight and egg diameter were observed in groups administrated with Ov $10 \mu \mathrm{gg} \mathrm{bw}^{-1}$ and $\mathrm{HCG}+$ Met (2000 IU kg bw $\left.{ }^{-1}\right)$ respectively. The highest values of absolute fecundity and relative fecundity were recorded for fish administrated with $\mathrm{Ov}\left(20 \mu \mathrm{g} \mathrm{kg} \mathrm{bw}^{-1}\right)$. The latency period and hour-degree for final maturation were lower in fish administrated with Ov $\left(10 \mu \mathrm{g} \mathrm{kg} \mathrm{bw}^{-1}\right)$ compared to other experimental groups $(\mathrm{p}<0.05)$. There were no significant differences between experimental groups in terms of other assayed parameters. The results of the present study demonstrated higher efficiency of ovaprim in improving the reproductive performance of Caspian shemaya.
\end{abstract}

Keywords: Alburnus chalcoides, Caspian shemaya, Human chorionic gonadotropin, Metoclopramide, Ovaprim, Pituitary extract

\section{Introduction}

The Caspian shemaya Alburnus chalcoides (Guldenstadt, 1772) is widely distributed in the Black, Caspian and Aral seas. Populations of the species occur mainly in the western to southern coast of the Caspian Sea and supports local subsistence fishery (Akyurt and Sari, 1991; Balik et al., 1996; Bogutskaia, 1997; Tarkan et al., 2005). Recently, the fish is considered to be vulnerable to endangered in the south Caspian Basin (Kiabi et al., 1999; Naderi and Abdoli, 2004), due to various reasons like damming of the rivers, overfishing during spawning season and deterioration of spawning grounds in the rivers and streams. Reproduction of Caspian shemaya in captive condition could be an appropriate way to produce juveniles for restocking programs and aquaculture goals. Generally, the reproductive cycle can be controlled by either placing the fish in an appropriate environment or by changing the internal regulating factors by injecting hormones or other substances. Artificial induction of fish spawning with hormonal treatments has been used for almost 60 years (Rottmann et al., 1991). The spawning induction in carps is usually achieved by the use of human chorionic gonadotropin (HCG), synthetic hormones and pituitary extract. Ovaprim (sGnRHa+Domperidone) is widely used for spawning induction of some carp species. The pituitary gland produces and stores gonadotropin hormones $(\mathrm{GTH})$, which play an important role in stimulation of ovulation and spermiation. HCG is purified gonadotropin hormone used for induction of spawning (Rottmann et al., 1991). HCG has been increasingly used for induction of spawning in many fish species. Furthermore, HCG acts directly on the gonads (Zohar and Mylonas, 2001). In the present study, we evaluated the effects of three hormonal treatment types i.e., pituitary extract $(\mathrm{Pt})$, Ovaprim $(\mathrm{Ov})$ and $\mathrm{HCG}+$ Metoclopramide (Met) at various doses, on the reproductive performance of Caspian shemaya Alburnus chalcoides. 


\section{Materials and methods}

Experimental design

The experiment was conducted at Sefidrood Fishery Research Center (SFRC), Astaneh Ashrafieh, Guillan Province, Iran. Broodstocks of Caspian shemaya were captured from downstream parts of Sardabrood River before onset of spawning season. The broodstocks were transferred to SFRC with proper aeration. Females and males were separated and stocked in different ponds to prevent natural spawning. Thirtysix healthy females (mean weight $=49.5 \pm 5.3 \mathrm{~g}$ ) were distributed in 12 glass aquaria (3 fish per aquarium) as 3 experimental treatments and one control group (without hormonal treatment) with three replicates each. Sex determination was made on the basis of morphologic features. The experimental groups were administrated with different doses of $\mathrm{Pt}, \mathrm{Ov}$, HCG+Met at doses of: Pt - $2 \mathrm{mg} \mathrm{kg} \mathrm{bw}{ }^{-1}, \mathrm{Pt}-3 \mathrm{mg} \mathrm{kg}$ $\mathrm{bw}^{-1}, \mathrm{Pt}-4 \mathrm{mg} \mathrm{kg} \mathrm{bw}{ }^{-1}$, Ov - $10 \mu \mathrm{g} \mathrm{kg} \mathrm{bw}{ }^{-1}$, Ov - $20 \mu \mathrm{g} \mathrm{kg}$ $\mathrm{bw}^{-1}, \mathrm{Ov}-30 \mu \mathrm{g} \mathrm{kg} \mathrm{bw}{ }^{-1}, \mathrm{HCG}+\mathrm{Met}-1000 \mathrm{IU} \mathrm{kg} \mathrm{bw}{ }^{-1}$, HCG+Met - $2000 \mathrm{IU} \mathrm{kg} \mathrm{bw}^{-1}$, HCG+Met - $3000 \mathrm{IU}$ kg $\mathrm{bw}^{-1}$ and control group (without any hormonal treatment). Before hormone injection, the fish were anaesthetised using clove oil extract (Eugenia caryophyllata) at $30 \mathrm{mg}^{-1}$ and then hormones were administered by intramuscular injection beneath the dorsal fin. After injection, the fish were placed immediately in the respective aquaria. The fishes were checked for ovulation after first injection at every $12 \mathrm{~h}$ interval upto ovulation. During the course of the experiment, the water quality parameters in each aquarium was monitored and maintained in normal range of: water temperature $-22^{\circ} \mathrm{C}$, dissolved oxygen $7.2 \pm 0.4 \mathrm{mg} \mathrm{l}^{-1}$ and $\mathrm{pH}-7.4 \pm 0.05$. When ovulated, the eggs were fertilised according to Billard et al. (1995) using pooled milt samples from three males $(39.5 \pm 3.5 \mathrm{~g})$ and then incubated separately in 71 capacity veis incubators until hatching i.e., 3-4 days after fertilisation. In swim-up stage, larvae were transferred to separate Zuger jars (200 1) and fed $10 \mathrm{~g}$ dried milk in each Zuger for one week.

\section{Reproductive indices}

The reproductive indices were investigated in two stages: (a) after injection (latency period, hour-degree for final maturation) and (b) after ovulation (duration of egg incubation, spawning rate, oocyte weight, egg diameter, number of eggs per gram, absolute fecundity, relative fecundity, fertilisation rate, hatching rate, larvae number and larval survival). These indices were calculated using the following formulae:

Spawning rate $=($ No. of ovulated fish $/$ Total no. of injected fish $) \times 100$

Fertilisation rate $=($ No. of fertilised eggs $/$ Total eggs $) \times 100$
Fertilisation rate was determined under a dissecting loop, $8 \mathrm{~h}$ after fertilisation, when the eggs were at the stage of gastrulation (Brommage and Cumalantunga, 1998).

$\begin{array}{ll}\text { Hatching rate }= & \text { (No. of viable embryos/Total number of eggs) } \\ & \times 100 \text { (Hanjavanit et al., 2008). } \\ \text { Latency period }= & \text { Time between first injection and ovulation } \\ & \text { (Drori et al., 1994) } \\ \text { Absolute fecundity = } & \text { Total number of eggs produced per broodfish } \\ \text { Relative fecundity = } & \text { Total number of eggs produced per broodfish/ } \\ & \text { body weight }(\mathrm{kg}) \\ = & \text { (Number of live larvae }- \text { Number of dead } \\ \text { Survival rate } & \text { larvae) } / \text { Number of live larvae } \times 100\end{array}$

\section{Statistical analysis}

Data normality was tested by Shapiro-Wilk test. Differences between means were analysed using one way analysis of variance (ANOVA) followed by Duncan's new Multiple Range test at minimum significance of $p<0.05$. Differences between means with non-normal distributed data were analysed with Kruskal-Wallis test. Then, MannWhitney test was applied to identify which groups were different. All results are presented as means \pm standard error of the mean (SEM).

\section{Results and discussion}

There were significant differences between experimental groups in terms of ovulation, oocyte weight and egg diameter (Table $1, \mathrm{p}<0.05$ ). Number of eggs, number of larvae and larval survival did not show significant differences between experimental groups (Table 1, $\mathrm{p}>0.05$ ). The highest values of oocyte weight and egg diameter were observed in fish administrated with Ov $\left(10 \mu \mathrm{g} \mathrm{kg} \mathrm{bw}^{-1}\right)$ and HCG+Met $\left(2000 \mathrm{IU} \mathrm{kg} \mathrm{bw}^{-1}\right)$ respectively (Table $1, \mathrm{p}<0.05$ ). Also, latency period (Fig. 1a), absolute fecundity (Fig. 1b), relative fecundity (Fig. 1c), hour-degree for final maturation (Fig. 1d) and hatching rate (\%) (Fig. 1g) showed significant differences between experimental groups $(\mathrm{p}<0.05)$. In this regard, the highest values of absolute fecundity and relative fecundity were recorded for fish administrated with $\mathrm{Ov}$ $\left(20 \mu \mathrm{g} \mathrm{kg} \mathrm{bw}^{-1}\right)$ (Fig. $1 \mathrm{~b}$ and $\left.\mathrm{c}, \mathrm{p}<0.05\right)$. The latency period and hour-degree for final maturation were lower in fish administrated with Ov $\left(10 \mu \mathrm{g} \mathrm{kg} \mathrm{bw}{ }^{-1}\right)$ compared to other experimental groups (Fig. 1a and $\mathrm{d}, \mathrm{p}<0.05$ ). Also, no significant differences were observed in incubation period (h-degree) between experimental groups (Fig. 1e), fertilisation rate (\%) (Fig. 1f) and duration of egg incubation (Fig. 1h) ( $\mathrm{p}>0.05)$.

For inducing artificial reproduction of Caspian shemaya in captivity, broodstocks undergoing stage IV of maturation were required. Therefore, all fish were captured 


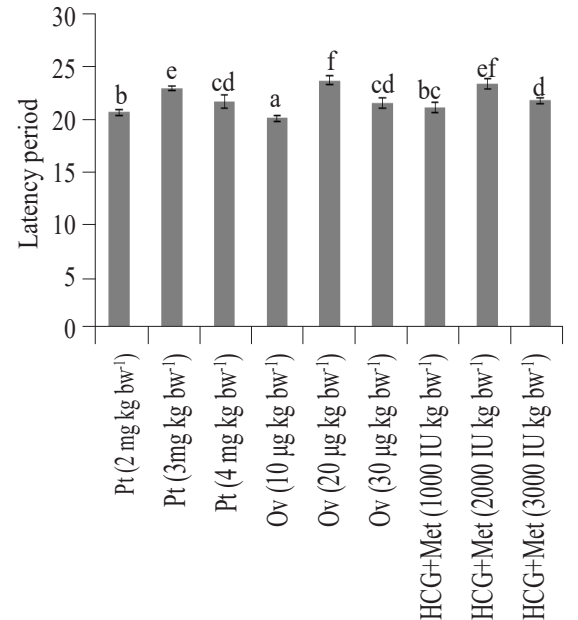

(a)

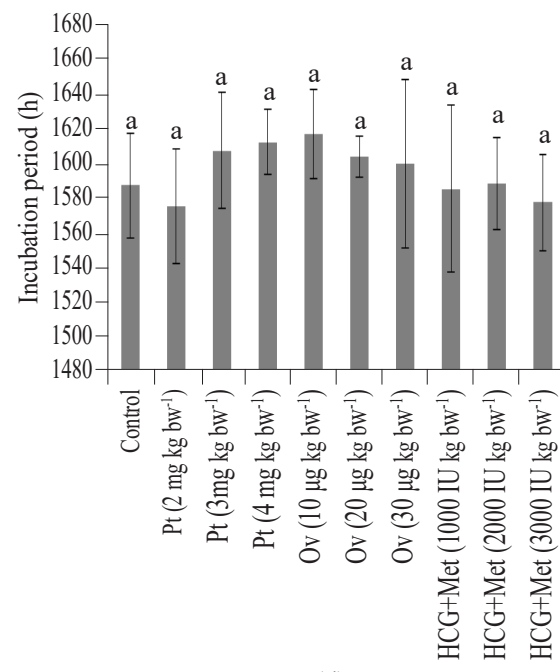

(d)

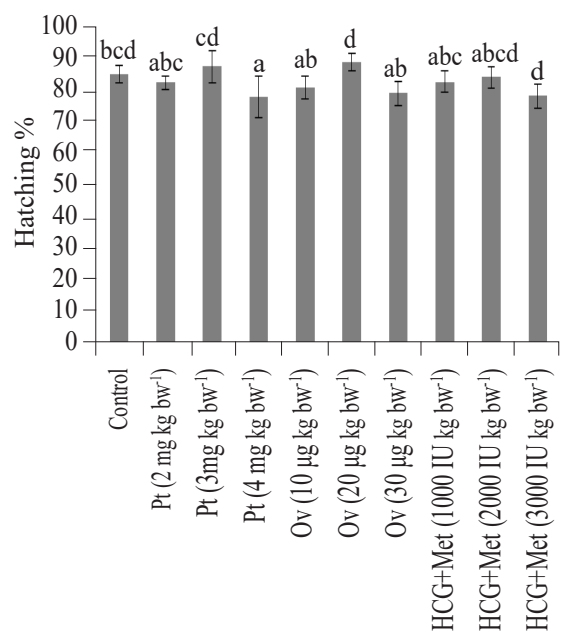

(g)

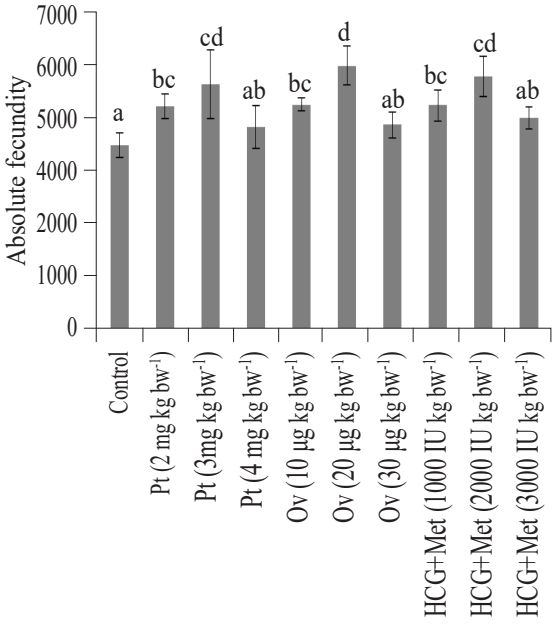

(b)

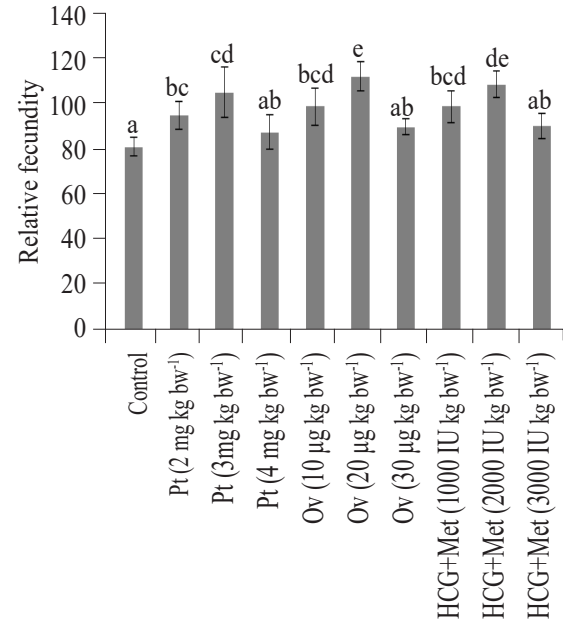

(c)

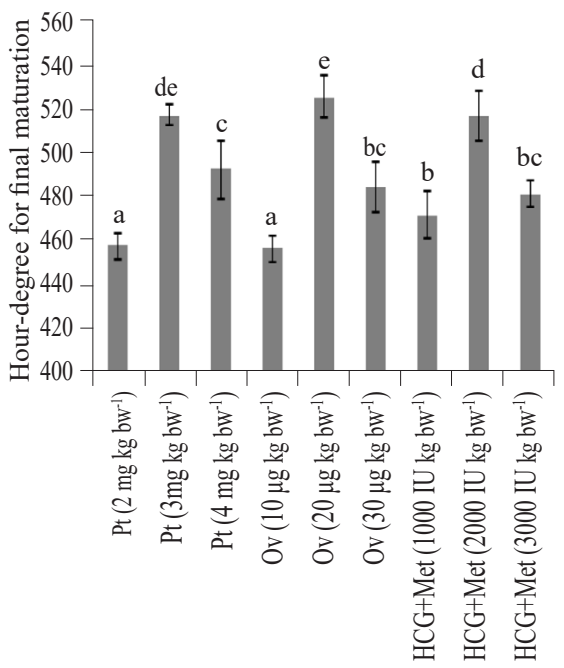

(e)

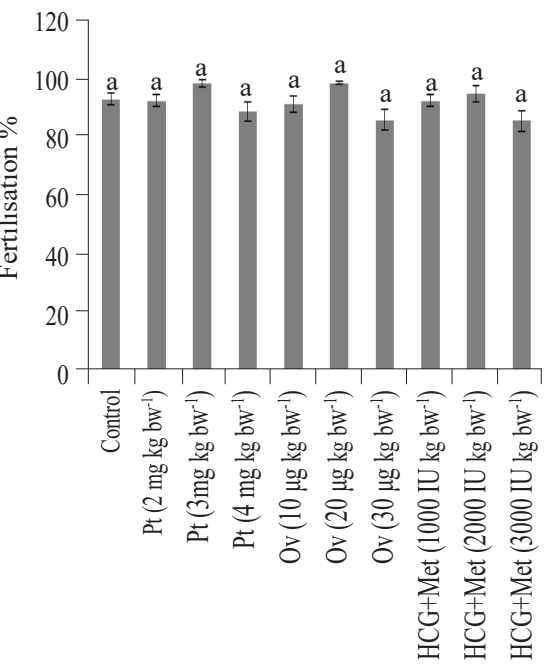

(f)

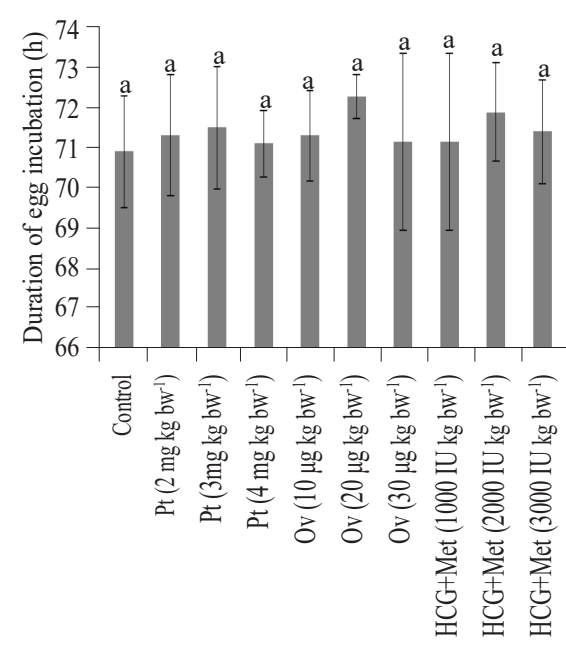

(h)

Fig. 1. Comparison of (a) Latency period, (b) Absolute fecundity (eggs per fish), (c) Relative fecundity (eggs per kg fish), (d) Incubation period (h), (e) Hour-degree for final maturation, (f) Fertilisation \%, (g) Hatching \% and (h) Duration of egg incubation (h) between experimental groups of A. chalcoides. Pt: Pituitary extract, Ov: Ovaprim, HCG: Human chorionic gonadotropin, Met: Metoclopramide, IU: International unit. Different letters indicate significant difference $(\mathrm{p}<0.05)$ 
Table 1. Comparison of selected reproductive parameters of Alburnus chalcoides between experimental groups

\begin{tabular}{|c|c|c|c|c|c|c|}
\hline Treatment geoup & $\begin{array}{l}\text { Ovulation } \\
(\%)\end{array}$ & $\begin{array}{l}\text { Oocyte weight } \\
(\mathrm{mg})\end{array}$ & $\begin{array}{l}\text { Egg number } \\
\text { (per g egg) }\end{array}$ & $\begin{array}{l}\text { Egg diameter } \\
(\mathrm{mm})\end{array}$ & Larvae number & $\begin{array}{l}\text { Larval survival } \\
(\%)\end{array}$ \\
\hline Control & 40 & $4.2 \pm 0.14^{\mathrm{a}}$ & $982 \pm 97.58^{\mathrm{a}}$ & $1.15 \pm 0.07^{\mathrm{bc}}$ & $3455 \pm 111.7^{\mathrm{a}}$ & $83.5 \pm 7.78^{\mathrm{a}}$ \\
\hline $\operatorname{Pt}\left(2 \mathrm{mg} \mathrm{kg} \mathrm{bw}^{-1}\right)$ & 100 & $5.46 \pm 0.31^{\mathrm{d}}$ & $919 \pm 55.86^{\mathrm{a}}$ & $1.1 \pm 0.07^{\mathrm{abc}}$ & $4080 \pm 255.6^{\mathrm{a}}$ & $73.2 \pm 7.33^{\mathrm{a}}$ \\
\hline $\operatorname{Pt}\left(3 \mathrm{mg} \mathrm{kg} \mathrm{bw}^{-1}\right)$ & 100 & $5.2 \pm 0.31^{\mathrm{cd}}$ & $970.6 \pm 30.5^{\mathrm{a}}$ & $1.14 \pm 0.09^{\mathrm{bc}}$ & $4031.8 \pm 172.7^{\mathrm{a}}$ & $77 \pm 6.44^{\mathrm{a}}$ \\
\hline $\mathrm{Pt}\left(4 \mathrm{mg} \mathrm{kg} \mathrm{bw}^{-1}\right)$ & 80 & $5.18 \pm 0.31^{\text {bcd }}$ & $970.25 \pm 38.1^{\mathrm{a}}$ & $1.13 \pm 0.05^{\mathrm{bc}}$ & $3839.5 \pm 700.4^{\mathrm{a}}$ & $81.25 \pm 3.59^{\mathrm{a}}$ \\
\hline Ov $\left(10 \mu \mathrm{g} \mathrm{kg} \mathrm{bw}{ }^{-1}\right)$ & 100 & $6.18 \pm 0.18^{\mathrm{e}}$ & $887.6 \pm 103.8^{\mathrm{a}}$ & $1.02 \pm 0.05^{\mathrm{a}}$ & $4740 \pm 641.4^{\mathrm{b}}$ & $84 \pm 4.06^{\mathrm{a}}$ \\
\hline Ov $\left(20 \mu \mathrm{g} \mathrm{kg} \mathrm{bw}{ }^{-1}\right)$ & 100 & $6.1 \pm 0.29^{\mathrm{e}}$ & $972 \pm 34.72^{\mathrm{a}}$ & $1.04 \pm 0.05^{\mathrm{ab}}$ & $5188.2 \pm 257.8^{\mathrm{b}}$ & $83 \pm 6.78^{\mathrm{a}}$ \\
\hline Ov $\left(30 \mu \mathrm{g} \mathrm{kg} \mathrm{bw}^{-1}\right)$ & 100 & $6.1 \pm 0.19^{\mathrm{e}}$ & $949 \pm 51.59^{\mathrm{a}}$ & $1.04 \pm 0.05^{\mathrm{ab}}$ & $4722.6 \pm 567.8^{\mathrm{b}}$ & $79.4 \pm 6.39^{\mathrm{a}}$ \\
\hline HCG+Met (1000 IU kg bw'-1) & 100 & $4.76 \pm 0.43^{\mathrm{bc}}$ & $951.8 \pm 21.18^{\mathrm{a}}$ & $1.18 \pm 0.08^{\mathrm{c}}$ & $3473.6 \pm 367.8^{\mathrm{a}}$ & $77.8 \pm 5.85^{\mathrm{a}}$ \\
\hline HCG+Met ( $\left.2000 \mathrm{IU} \mathrm{kg} \mathrm{bw}^{-1}\right)$ & 80 & $4.73 \pm 0.33^{\mathrm{b}}$ & $969.75 \pm 8.96^{\mathrm{a}}$ & $1.2 \pm 0.08^{\mathrm{c}}$ & $3569.5 \pm 188.2^{\mathrm{a}}$ & $76 \pm 4.24^{\mathrm{a}}$ \\
\hline HCG+Met (3000 IU kg bw-1) & 80 & $4.93 \pm 0.24^{\mathrm{bc}}$ & $962.5 \pm 12.72^{\mathrm{a}}$ & $1.18 \pm 0.1^{\mathrm{c}}$ & $3665.8 \pm 302.7^{\mathrm{a}}$ & $75.6 \pm 8.26^{\mathrm{a}}$ \\
\hline
\end{tabular}

Pt: Pituitary extract, Ov: Ovaprim, HCG: Human chorionic gonadotropin, Met: Metoclopramide, IU: International unit.

Values bearing different superscripts indicate significant difference $(\mathrm{p}<0.05)$

from downstream of Sefidrood, since a previous study has showed that almost all the fishes of this area were in stage IV of maturation (Abbasi et al., 1999). According to the results, the shortest latency period was found for fish administrated with Ov $\left(10 \mu \mathrm{g} \mathrm{kg} \mathrm{bw}{ }^{-1}\right)$ and Pt $(2 \mathrm{mg} \mathrm{kg}$ $\left.\mathrm{bw}^{-1}\right)$ respectively. Nevertheless, there were no significant differences between these treatments with others such as $\mathrm{HCG}+$ Met (1000 IU kg bw $\left.{ }^{-1}\right)$. In fish, duration of latency period is dependent on factors like water temperature, biological characteristics (species, age and weight), hormone type and numbers of injections (Billard, 1990; Yaron, 1995). In our study, the holding conditions for fish were similar and thus the differences between treatments may be associated with the dose of administrated hormone. However, in some studies, the action of $\mathrm{Pt}$ in lower levels of hypothalamic-pituitary-gonadal axis (HPG) than gonadotropin releasing hormone $(\mathrm{GnRH})$ was stated as reason for shorter latency period obtained by $\mathrm{Pt}$ (Epler, 1986). Spawning rate is one of the good indices for evaluation of hormonal effects on ovulation (Szabo et al., 2002). All administrated fish had higher spawning rate compared to control group with best results in $\mathrm{Ov}$ treatments. This results show that Ov could be used for induction of ovulation in addition to HCG and Pt for Caspian shemaya. Several studies have reported the effects of hormonal induction of reproduction on reproductive parameters such as fecundity, egg number, egg diameter, egg weight, larval number and larval survival (Rowland, 1983; Haraldsson et al., 1993; Legendre and Oteme, 1995; Mylonas et al., 1996; Sahoo et al., 2005; DiMaggio et al., 2013). Higher egg diameter was obtained in Ov treatments than in HCG, Pt and control groups. Several studies have revealed the positive relationships of egg diameter with egg quality (Zhukinskii and Gosh, 1988). Thus, Ov can improve egg quality in this respect. The values of absolute and relative fecundity in Ov $\left(20 \mu \mathrm{g} \mathrm{kg} \mathrm{bw}{ }^{-1}\right), \operatorname{Pt}(3 \mathrm{mg} \mathrm{kg}$ $\left.\mathrm{bw}^{-1}\right)$ and HCG (2000 IU $\mathrm{kg} \mathrm{bw}^{-1}$ ) groups were higher than in control and other experimental groups which demonstrated that these hormones stimulate ovulation successfully in a dose-dependent pattern.

Results of the present study enhanced our knowledge on reproductive abilities of Caspian shemaya in captive conditions and also helped to compare different methods of artificial induction to determine the best method for controlled spawning in Caspian shemaya.

\section{References}

Abbasi, K., Valipour, A., Talebi Haghighi, D., Sarpanah, A. and Nezami, S. 1999. Atlas of Iranian fishes. Guilan Inland Waters. Guilan Fisheries Research Center, Rasht, 113 pp.

Akyurt, I. and Sari, M. 1991. Investigation on some bioecological properties of the shemaya (Chalcalburnus chalcoides Guldenstaedt, 1772) living in different habitats. J. Fish. Aqua. Sci., 8(31-32): 87-101.

Balik, S. R., Ustaoglu, R., Sari, H. S. and Ozbek, M. 1996. Investigation on biological characteristics of the Danube bleak (Chalcalburnus chacoides Guldenstaedt, 1772) population in lake Kus (Bandirma). J. Fish. Aqua. Sci., 13: 171-182.

Billard, R. 1990. The major carps and other cyprinids. In: Nash, C. E. (Ed.), Production of Aquatic animals (fishes), Elsevier Science, p. 21-55.

Billard, R., Cosson, J., Perchec, G. and Linhart, O. 1995. Biology of sperm and artificial reproduction in carp. Aquaculture, 129(1-4): 95-112. doi.org/10.1016/0044-8486(94)00231-C.

Bogutskaya, N. G. 1997. Contribution to the knowledge of leuciscine fishes of Asia Minor. Part 2. An annotated check list of leuciscine fishes (Leuciscinae, Cyprinidae) of Turkey with description of a new species and two subspecies. Mitteilungenausdem Hamburgischen Zoologischen Museum und Institut, 94: 161-186.

Bromage, N. and Cumaranatunga, R. C. 1988, Egg production in the rainbow trout. In: Muir, J. F. and Roberts, R. J. (Eds.), 
Recent advances in aquaculture, Croom Helm, London, p. 63-138.

DiMaggio, M. A., Broach, J. S. and Ohs, C. L. 2013. Evaluation of ovaprim and human chorionic gonadotropin doses on spawning induction and egg and larval quality of pinfish, Lagodon rhomboides. Aquaculture, 414-415: 9-18. DOI: 10.1016/j.aquaculture.2013.07.012.

Drori, S., Ofir, M., Sivan, B. L. and Yaron, Z. 1994. Spawning induction in common carp (Cyprinus carpio) using pituitary extract or GnRH super active analogue combined with methoclopramide: analysis of hormone profile, progress of oocyte maturation and dependence on temperature. Aquaculture, 119(4): 393-407. doi.org/10.10 16/0044-8486(94)90303-4.

Epler, P., Sokolowska, M., Popek, W. and Bieniarz, K. 1986. Joint action of carp (Cyprinus carpio L.) pituitary homogenate and human chorionic gonadotropin (HCG) in carp oocyte maturation and ovulation: in vitro and in vivo studies. Aquaculture, 51(2): 133-142. https://doi. org/10.1016/0044-8486 (86)90134-1.

Hanjavanit, C., Kitancharoen, N. and Rakmanee, C. 2008. Experimental infection of aquatic fungi on eggs of African catfish (Clarias gariepinus Burch). KKU Sci., 36: 36-43.

Haraldsson, H., Sveinsson, T. and Skulason, S. 1993. Effects of LHRHa treatments upon the timing of ovulation and upon egg and offspring quality in Arctic charr, Salvelinus alpinus (L.). Aquacult. Res., 24(2): 145-150. DOI: 10.1111/j.13652109.1993.tb00534.x.

Kiabi, B. H., Abdoli, A. and Naderi, M. 1999. Status of the fish fauna in the south Caspian basin of Iran. Zool. Midd. East., 18(1): 57-65. doi.org/10.1080/09397140.1999.10637782.

Legendre, M. and Oteme, Z. 1995. Effect of varying latency period on the quantity and quality of ova after HCG induced ovulation in the African catfish Heterobranchus longifilis (Teleostei, Clariidae). Aquatic Living Resour., 8(4): 309-316. doi.org/10.1051/alr:1995032.

Mylonas, C. C., Magnus, Y., Gissis, A., Klebanov, Y. and Zohar, Y. 1996. Application of controlled release, GnRHadelivery systems in commercial production of white bass striped bass hybrids (Sunshine bass), using captive brood stocks. Aquaculture, 140(3): 265-280. DOI: 10.1016/00448486(95)01178-1.
Naderi, M. and Abdoli, A. 2004. Fish species atlas of south Caspian Sea basin (Iranian waters). Iranian Fisheries Research Organisation, Teharn, 80 pp. (in Persian and English).

Rottmann, R. W., Shireman, J. V. and Chapman, F. A. 1991. Determining sexual maturity of broodstock for induced spawning of fish. SRAC Publication, 423: 1-4.

Rowland, S. J. 1983. The hormone-induced ovulation and spawning of the Australian freshwater fish golden perch, Macquariaam bigua (Richardson) (Percichthyidae). Aquaculture, 35: 221-238. doi.org/10.1016/0044-8486 (83)90093-5.

Sahoo, S. K., Giri, S. S. and Sahu, A. K. 2005. Induced spawning of Asian catfish, Clarias batrachus (Linn.): effect of various latency periods and sGnRHa and domperidone doses on spawning performance and egg quality. Aquac. Res., 36(13): 1273- 1278. DOI: 10.1111/j.13652109.2005.01317.x.

Szabo, T., Medgyasszay, C. and Horváth, L. 2002. Ovulation induction in nase (Chondrostoma nasus, Cyprinidae) using pituitary extract or GnRH analogue combined with domperidone. Aquaculture, 203(3-4): 389-395. https://doi. org/10.1016/s0044-8486(01)00635-4

Tarkan, A. S., Gaygusuz, O., Acipinar, H. and Gursoy, C. 2005. Characteristics of a Eurasian cyprinid, Shemaya, Chalcalburnus chalcoides (Guldenstadt, 1772), in a mesotrophic water. Z. Midd. East., 35(1): 49-60.

Yaron, Z. 1995. Endocrine control of gametogenesis and spawning induction in the carp. Aquaculture, 129(1-4): 49-73. https://doi.org/10.1016/0044-8486(94)00229-h.

Zhukinskii, V. N. and Gosh, R. I. 1988. Criteria of biological quality of ovulated eggs in cultured fishes and a method of its express-assessment. Vopr. Ikhtiol., 28: 773-81 (in Russian).

Zohar, Y. and Mylonas, C. C. 2001. Endocrine manipulation of spawning induction in cultured fish from hormone to gene. Aquaculture, 197(1): 99-139. DOI: 10.1016/S00448486(01)00584-1. 